\title{
Characterization and optimization of xylanase producing strain of Bacillus subtilis isolated from the cabbage looper (Trichoplusia ni (Hübner)) intestine
}

\author{
Nipaponr Chitchaowana ${ }^{1}$, Wichuda Klawech ${ }^{2}$, Suparat Sutthimusik ${ }^{3}$ and Monthon Lertworapreecha ${ }^{4 *}$ \\ ${ }^{1}$ Faculty of Science, Thaksin University, Phatthalung, 93210, Thailand. \\ ${ }^{2}$ School of Biological and Environmental Science, Faculty of Science, Thaksin University, Phatthalung, 93210, \\ Thailand. \\ ${ }^{3}$ School of Biological Science, Faculty of Science, Thaksin University, Phatthalung, 93210, Thailand. \\ ${ }^{4}$ Microbial Resource Management Research Unit, and School of Biological Science, Faculty of Science, \\ Thaksin University, Phatthalung, 93210, Thailand. \\ Email: worapreecha@gmail.com
}

Received 10 October 2015; Received in revised form 18 January 2016; Accepted 18 May 2016

\begin{abstract}
Aims: To characterize xylanolytic enzyme producing strains of Bacillus subtilis from the intestinal tract of a cabbage looper (Trichoplusia ni (Hübner)) larvae.

Methodology and results: Approximately $5 \mathrm{~g}$ of intestinal content from the instar larvae were homogenated and serially diluted $10^{-4}-10^{-6}$ times with sterile normal saline before being spread onto duplicate tryptic soy agar plates. Every different colony was selected to test for xylanase production. Of six isolates, only one was found to be positive for xylanase production by screening agar. Biochemical characteristics and 16S rRNA gene sequencing indicated that the Bact-I was closely related to Bacillus subtilis. Optimization of xylanase enzyme production showed that Bacillus subtilis was able to produce xylanase enzymes when grown in a culture medium containing $2 \%(\mathrm{w} / \mathrm{v})$ corn stover and $0.6 \%(\mathrm{w} / \mathrm{v})$ yeast extract at $\mathrm{pH} 10$ and $37^{\circ} \mathrm{C}$. The xylanase gene was cloned and characterized. The result revealed that the xylanase gene of Bacillus subtilis was homology to the $\beta-1,4$ endo-xylanase gene.

Conclusion, significance and impact of study: A xylanase producing Bacillus subtilis was isolated from the intestinal tract of a cabbage looper (Trichoplusia ni (Hübner)) larvae. Optimization and evaluation of the xylanase activity of Bacillus subtilis indicated that it could be useful for xylanase production or as a probiotic for improving animal feed stuff.
\end{abstract}

Keywords: Xylanase, Bacillus subtilis, Trichoplusia ni, intestinal tract

\section{INTRODUCTION}

Xylan compounds such as lignocellulosic biomass are the most abundant renewable organic materials found in agriculture (Kayserilioglu et al., 2003; Faik, 2010). They have complex structures, which consist of substituent groups of acetyl I, 4-O-methyl-D-glucuronosyl and Larabinofuranosyl residues, linked to the backbone of $\beta$ 1,4-linked xylopyranosyl units (Bastawde, 1992). However, the utilization of agricultural waste requires improvement processes, such as the digestion of hemicellulosic enzymes prior to use. The enzyme used for xylan degradation is xylanase. This enzyme is widely used in many facets of the food and beverage industry, animal feed improvement and also for the bioethanol production industry (Beg et al., 2001; Polizeli et al., 2005).

Almost all of the xylanase used in industry is produced from microorganisms. Therefore, several xylanase producing microorganisms have been isolated from various sources, such as natural water, soil and the intestinal contents of various ruminant species, as well as assorted insect species (Cordeiro et al., 2002; Ninawe et al., 2006; Menon et al., 2010; Subramaniyan, 2012). In contrast to mammals, insect larvae such as that of the cabbage looper, the instar larva of the T. ni (Hübner), are fascinating because they feed on plant leaves. The fact that they have a very short digestive tract, when compared to ruminants, which enables them to eat and digest plant matter with efficiency, is also of interest. Presumably, this may be due to the microbial flora within the gut of the butterfly larva producing the most powerful cellulolytic enzymes, including xylanase, which help in the digestion of fibrous compounds. Therefore, we conducted a study to isolate and identify the xylanase producing bacteria from the gut of T. ni (Hübner).

\section{${ }^{*}$ Corresponding author}




\section{MATERIALS AND METHODS}

\section{Samples and microorganism isolation}

The fourth or fifth instar larvae of $T$. ni (Hübner) were collected from a cabbage. Five to six instar larvae (approximately $5 \mathrm{~g}$ of intestine) were used in this study. The surface area of the instar larva was sterilized twice with $70 \%(\mathrm{v} / \mathrm{v})$ ethanol for $5 \mathrm{~min}$ and then treated once with $3 \%(\mathrm{v} / \mathrm{v})$ sodium hypochlorite. Finally, the instar larva was washed twice in sterile normal saline and then allowed to air dry in a Class-II biosafety cabinet. The digestive tract was aseptically removed from the larva with caution. The digestive tracts were chopped and homogenized in a $15 \mathrm{~mL}$ centrifuge tube using a sterile stirring rod. The homogenate was serially diluted $10^{-4}-10^{-6}$ times with sterile normal saline before being spread onto duplicate tryptic soy agar plates (TSA: Himedia; India). The plates were then incubated separately at $37^{\circ} \mathrm{C}$ for 18 to $24 \mathrm{~h}$. Every different colony was selected to test for gram strain and xylanase production (Cordeiro et al., 2002).

\section{Screening for xylanase production}

Screening for xylanase production was performed on xylan agar (composition in $1 \mathrm{~L}$ : birch wood xylan $2.5 \mathrm{~g}$, yeast extract $5 \mathrm{~g}$, peptone $5 \mathrm{~g}, \mathrm{MgSO}_{4} 0.2 \mathrm{~g}, \mathrm{~K}_{2} \mathrm{HPO}_{4} 1 \mathrm{~g}$ and agar $15 \mathrm{~g}$ ) (Sanghi et al., 2008). Approximately $5 \mu \mathrm{L}$ of each overnight culture from Tryptic Soy Broth (TSB: Himedia; India) was dropped onto xylan agar and incubated at $37{ }^{\circ} \mathrm{C}$ for 18 to $24 \mathrm{~h}$. In order to test for enzyme production, the plate was stained by overlaying with an iodine solution $(2 \% \mathrm{w} / \mathrm{v}$ of iodine, $3 \% \mathrm{w} / \mathrm{v}$ potassium iodide mixed in distilled water) for 1-2 min. Xylanase production was observed in a clear zone around the colony. Only those isolates that produced a clear zone were selected for further observation (Cordeiro et al., 2002).

\section{Biochemical and molecular identification by $16 \mathrm{~S}$ rDNA gene sequencing analysis}

The biochemical properties of the isolate were characterized by HiBacillus ${ }^{T m}$ identification kit (Himedia; India). The biochemical characteristics were identified according to standard protocols (Himedia, 2015). For molecular identification, bacterial isolates were grown on tryptic soy agar (TSA: Himedia; India) at $37^{\circ} \mathrm{C}$ for $24 \mathrm{~h}$. Then, 2-3 colonies of bacteria were collected in $200 \mu \mathrm{L}$ of TE buffer. The bacterial cell was vortex mixed and boiled for $10 \mathrm{~min}$. Extracted cells were stored at $-20{ }^{\circ} \mathrm{C}$ until further analysis was conducted. Universal 16S rRNA primers Bact-0341 5'-CCTACGGGNGGCWGCAG-3' and Bact-0785 5'-GACTACHVGGGTATCTAATCC-3' were used in this study (Klindworth et al., 2013). A polymerase chain reaction (PCR) was performed in a thermocycler (CC590 Bio-Rad, USA). Each reaction mixture $(25 \mu \mathrm{L})$ contained $1 \times$ buffer, $4 \mathrm{mM} \mathrm{MgCl}$, 50 pmole of each primer, $0.2 \mathrm{mM}$ of each dNTP, $1.25 \mathrm{U}$ of Taq DNA polymerase (iTaq; Bio-Rad) and $25 \mathrm{ng}$ of template DNA. The amplifications were performed as follow: initial denaturation for $10 \mathrm{~min}$ at $94{ }^{\circ} \mathrm{C}, 40$ cycles each of denaturation for $50 \mathrm{sec}$ at $94^{\circ} \mathrm{C}$, annealing for $50 \mathrm{sec}$ at $56{ }^{\circ} \mathrm{C}$, and primer extension for $1 \mathrm{~min}$ at $72{ }^{\circ} \mathrm{C}$. A final extension was performed for $10 \mathrm{~min}$ at $72{ }^{\circ} \mathrm{C}$. The PCR products were analyzed by gel electrophoresis in $1.2 \%$ $(\mathrm{w} / \mathrm{v})$ agarose gels and stained with ethidium bromide (10 $\mathrm{mg} / \mathrm{mL}$ ). PCR products were purified using a gel extraction kit (Spinclean ${ }^{\mathrm{TM}}$ PCR purification kit). Sequences were aligned against those found in the NCBI database by Bioedit and MEGA 6 program.

\section{Cloning of the xylanase gene}

Bacterial DNA was subjected to amplification of the xylanase gene using specific primers derived from previous report: xynF: ACGAATTCCATGTTTAAGTTTAAAAAGAATTTCTTAGT T-3', xynR: 5'-GAGGATCCTTACCACACTGTTACGTTA GACTTCCACT-3' (Huang et al., 2006). The PCR reaction mixtures contained $1 \times$ of Taq reaction buffer, $0.2 \mathrm{mM}$ dNTPs, $100 \mathrm{ng}$ of genomic DNA, and $1 \mathrm{U}$ of DNA Taq polymerase (iTaq; Bio-Rad) in a final volume of $50 \mu \mathrm{L}$. Amplification reactions were performed as described, with initial denaturation at $94^{\circ} \mathrm{C}$ for $10 \mathrm{~min}, 40$ cycles each of denaturation at $94{ }^{\circ} \mathrm{C}$ for 1 min followed by annealing at $55{ }^{\circ} \mathrm{C}$ for $1 \mathrm{~min}$ and primer extension at $72{ }^{\circ} \mathrm{C}$ for $1 \mathrm{~min}$, and a final extension step at $72{ }^{\circ} \mathrm{C}$ for $10 \mathrm{~min}$. The amplicons were analyzed by gel electrophoresis. The PCR product was purified before insertion into the plasmid $\mathrm{pTZ57R/T}$ (Isn TAclone Kit; Thermo Scientific: USA) and followed by transformation into Escherichia coli (DH5- $\alpha)$. The plasmid was extracted and purified before analyzing the nucleotide sequence. The amplified gene sequence was analyzed by Biobasic (Canada). Sequence alignment was employed using BLAST software from the GenBank. Alignment of the sequences determined was performed with a Bioedit program.

\section{Enzymatic activity assay}

Total xylanase activity in the culture media was determined with reducing sugars by dinitro salicylic acid (DNS) method (Miller, 1959). In brief, bacteria was grown in $50 \mathrm{~mL}$ of nutrient broth (NB: Himedia; India) at $37^{\circ} \mathrm{C}$ for $48 \mathrm{~h}$. Then, $10 \mathrm{~mL}$ of inoculum was added to the xylan solution $(0.2 \% \mathrm{w} / \mathrm{v}$ birch wood xylan in sterile distilled water) and incubated at $37^{\circ} \mathrm{C}$ for $48 \mathrm{~h}$. The supernatant was collected by centrifugation at $10,000 \mathrm{rpm}$ at $4{ }^{\circ} \mathrm{C}$ for $10 \mathrm{~min}$. After that, $0.5 \mathrm{~mL}$ of $1 \%(\mathrm{w} / \mathrm{v})$ xylan solution, 0.5 $\mathrm{mL}$ of crude enzyme and $0.5 \mathrm{~mL}$ of $0.1 \mathrm{M}$ sodium phosphate buffer $\mathrm{pH} 7$ were mixed together and incubated for $10 \mathrm{~min}$ at $50{ }^{\circ} \mathrm{C}$. Subsequently, $1 \mathrm{~mL}$ of DNS solution was added to the tube. After mixing thoroughly, samples were boiled for $15 \mathrm{~min}$ and immediately cooled in ice water for stabilization of color. The reactions were added to $2 \mathrm{~mL}$ of distilled water prior to measurement with an absorbance at $540 \mathrm{~nm}$ using a spectrophotometer (ThermoSpectronic, USA) (Cordeiro et 
al., 2002). The standard curve of xylose was used to determine xylanase activity. One unit of xylanase activity is defined as the amount of enzyme releasing $1 \mu \mathrm{mol}$ of reducing sugar equivalent to xylose per minute.

\section{Optimization of xylanase production}

The optimization of xylanase production was carried out based on stepwise modification of the various parameters for the growth of bacteria. For carbon source utilization, various concentrations $(0.5,1,1.5$ and $2 \%)$ of rice straw, corn stover and corn cob were used as carbon sources in the production medium (composition in $1 \mathrm{~L}$ : yeast extract $5 \mathrm{~g}$, peptone $5 \mathrm{~g}, \mathrm{MgSO}_{4} \cdot 7 \mathrm{H}_{2} \mathrm{O} 0.2 \mathrm{~g}, \mathrm{~K}_{2} \mathrm{HPO}_{4} 0.4 \mathrm{~g} \mathrm{pH} 7$ ) (Sanghi et al., 2008). The optimization of nitrogen source was carried out with various concentrations $(0.2,0.3,0.4$, 0.5 and $0.6 \%$ ) of yeast extract, peptone, ammonium sulphate and urea in the production medium containing the optimal carbon source. The effect of $\mathrm{pH}$ was performed by varying the $\mathrm{pH}$ from 6 to 10 in the production medium containing the optimal carbon and nitrogen sources. The effect of cultivation temperature on the growth and enzyme production was examined at 30 , 37 and $40{ }^{\circ} \mathrm{C}$.

\section{Statistical analysis}

The results of enzyme production in each optimized condition were analyzed by GraphPad Prism program (V 5.0). All statements of significance were calculated using one-way ANOVA method, based on a confidence level of $95 \%$.

\section{RESULTS AND DISCUSSION}

\section{Isolation of xylanase producing bacteria}

In this study, bacterial samples were isolated from the intestinal tract of $T$. ni (Hübner) larvae. Only different bacterial colonies were selected to screen for xylanase production in a xylan medium. Altogether, 6 different bacterial colonies were isolated (Bact-I, Bact-II, Bact-III, Bact-IV, Bact-V and Bact-VI). However, only 1 isolate (Bact-I) was found to be positive for xylanase production by screening agar (Figure 1).

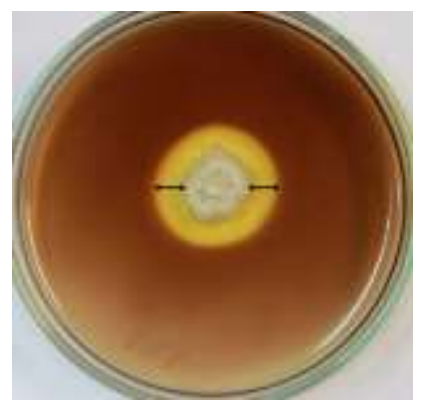

Figure 1: Hydrolysis zone produced by Bacillus subtilis (Bact-I) on xylan agar.

\section{Identification of xylanase producing bacteria}

Morphology and Gram strain indicated that the Bact-I isolate was Gram positive for bacilli. The preliminary results of morphological and biochemical characteristics suggested that this isolate closely related to Bacillus subtilis. The Bact-I isolate was further confirmed by $16 \mathrm{~S}$ rRNA gene sequencing. The nucleotides blast against the GenBank database demonstrated a consistent result, which indicated that this strain had $98 \%$ similarity to $B$. subtilis (Table 1 and Figure 2).

Table 1: Biochemical characteristic tested for the isolate Bact-I (HiBacillus ${ }^{\mathrm{Tm}}$ identification kit).

\begin{tabular}{lc}
\hline Biochemical reactions & Bact-I \\
\hline Malonate & - \\
VogesProskauer's & + \\
Citrate & + \\
ONPG & + \\
Nitrate reduction & + \\
Catalase & + \\
Arginine & - \\
Sucrose & + \\
Manital & + \\
Glucose & + \\
Arabinose & + \\
Trehalose & + \\
\hline
\end{tabular}

Bacillus spp. is a spore-forming Gram positive bacteria. These bacteria are normally found in environments including the intestinal tract of humans and various animals. It is not a pathogenic strain in animals. This result is according to previous reports that have described the isolation of bacteria from the digestive tract of different insects indicating that Bacillus spp. was the main genus found in insect intestines (Gusmão et al., 2007; Anand et al., 2010). Since these results were from single-sampling experiments, we were unable to determine whether $B$. subtilis is a normal flora bacteria or just a temporary colonization in the insect larva. However, the ability to produce xylanase enzyme probably implies that this strain plays an important role in the digestion of hemicellulose compounds in the intestines of the T. ni (Hübner) larvae.

\section{Optimization of xylanase production}

To optimize the conditions for xylanase production from $B$. subtilis (Bact-I), various types of hemicellullose (rice straw, corn stover and corn cob), nitrogen sources (yeast extract, peptone, ammonium sulphate and urea), $\mathrm{pH}$ and temperature were used to create the optimal conditions for xylanase production. It was found that $B$. subtilis (Bact-I) produced the highest level of xylanase with statistical significance $(p<0.001)$ when cultured in a medium composed of $2 \%(\mathrm{w} / \mathrm{v})$ corn stover, which produced enzyme activity equal to $1.5 \mathrm{U} / \mathrm{mL}$ at $24 \mathrm{~h}$. For optimization of the nitrogen sources, $2 \%$ of corn stover was used as a carbon source in the culture medium 
containing various types of nitrogen sources. The results found that yeast extract at $0.6 \%$ was able to induce the highest level of xylanase production, which produced enzyme activity equal to $1.2 \mathrm{U} / \mathrm{mL}$ at $12 \mathrm{~h}(p<0.001)$. The best suitable $\mathrm{pH}$ to produce xylanase was 10 , with the optimal temperature for growth of bacteria at $37^{\circ} \mathrm{C}$ (Figure 3).

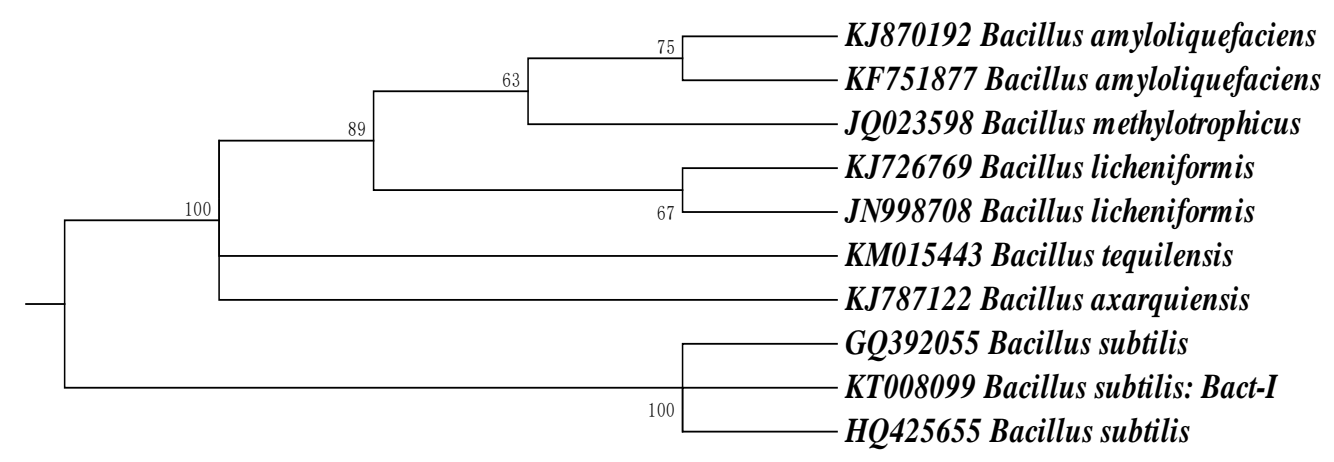

Figure 2: A. Nucleotides sequence analysis of 16S rRNA gene (accession number: KT008099) of Bacillus subtilis (BactI) against sequence retrieved from the GenBank database. The phylogenetic tree was performed with a Bioedit and MEGA 6 program (Neighbor Joining: 1,000 bootstrap).
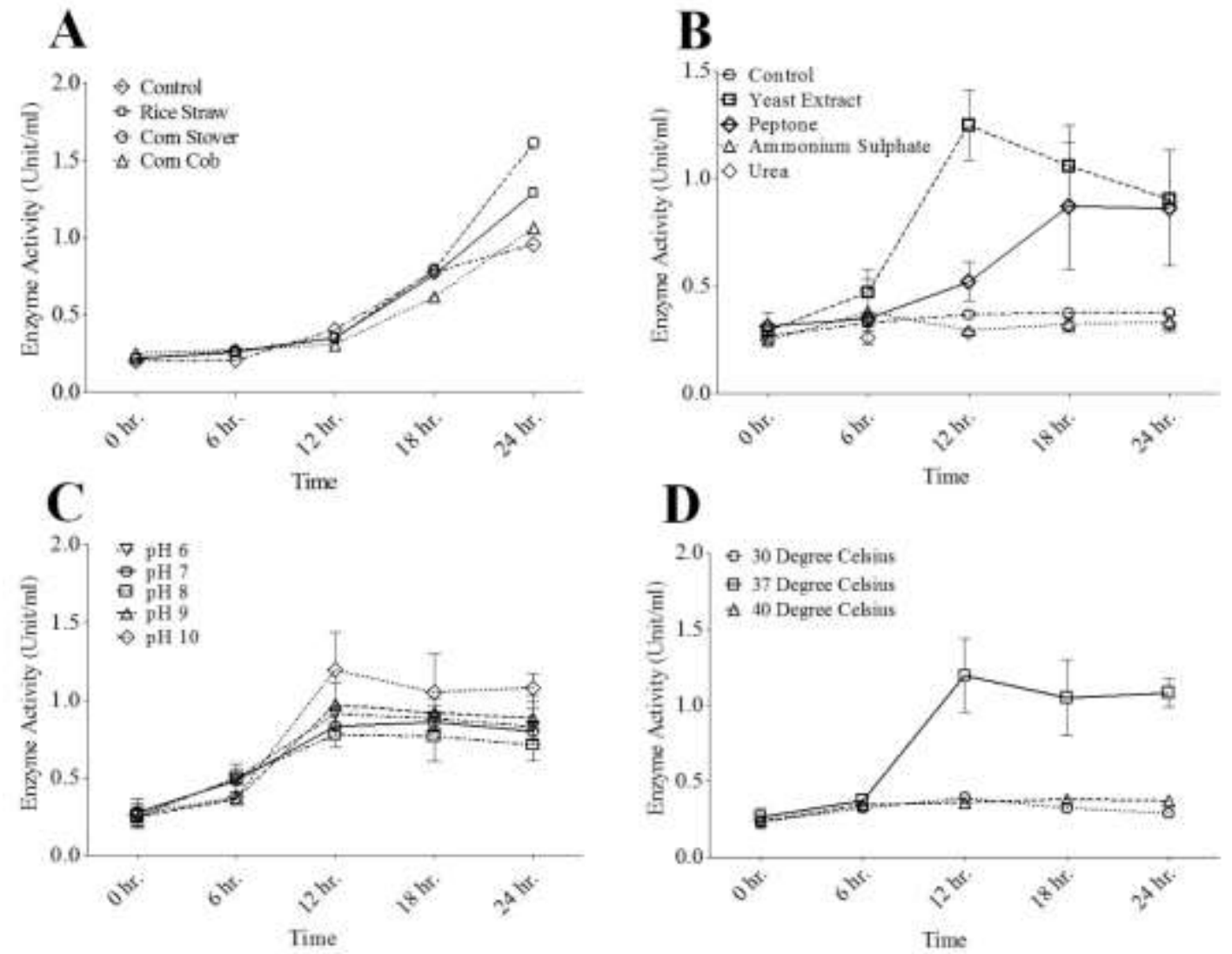

Figure 3: Enzyme activity of $B$. subtilis (Bact-I) cultured in various condition. A, the enzyme activity observed from various carbon sources; $B$, the enzyme activity observed from $2 \%$ of corn stover and various nitrogen sources; $C$, the enzyme activity observed from $2 \%$ of corn stover, $0.6 \%$ of yeast extract and various $\mathrm{pH}$ conditions; $\mathrm{D}$, the enzyme activity observed from $2 \%$ of corn stover, $0.6 \%$ of yeast extract at $\mathrm{pH} 10$ and various growth temperature. All experiments were done in duplicate and showed as mean and SD. ${ }^{* *}$ Statistical analysis significantly $(p<0.001)$. 
Xylanase activity indicated that the $B$. subtilis (Bact-I) is a potential strain when compared to other xylanaseproducing Bacillus spp. from previous reports in Thailand, which displayed circa $1.6 \mathrm{U} / \mathrm{mL}$ (Leartslarus et al., 2002). Interestingly, our results indicated that the xylanase from $B$. subtilis (Bact-I) is an alkaline and probably a thermotolerant xylanase. This is because the optimal $\mathrm{pH}$ and temperature of xylanase function were 10 and $50{ }^{\circ} \mathrm{C}$, respectively. Optimization by varying the carbon sources indicated that corn stover was the best carbon source to induce xylanase production. This was consistent with previous studies, which showed that corn stover was the most suitable substrate for the production of xylanase from microorganisms (Leartslarus et al., 2002; Selig et al., 2008; Ghori et al., 2011). This may be due to the fact that corn stover contains sufficient xylan and more than the other hemicelluloses used in this study.

\section{Xylanase gene cloning and nucleotides analysis}

The PCR used specific primers for the xylanase gene, which resulted in amplicons of approximately $600 \mathrm{bp}$. The amplicon was inserted into a plasmid pTZ57R/T TAcloning vector and transformed into $E$. coli DH5- $\alpha$. The partial nucleotide sequence of the insert was determined in one direction and one open reading frame of $600 \mathrm{bp}$ encoding protein comprised of 181 amino acid residues. The nucleotide blast against the sequence from the GenBank database indicated that this xylanase gene is $100 \%$ identical to the $\beta-1,4$ endo-xylanase gene (EU233656) (Figure 4). According to previous reports, this indicated that most of the bacteria produced endoxylanase enzymes other than exo-xylanase enzymes (Anand et al., 2013; Bhalla et al., 2014; Sheng et al., 2014).

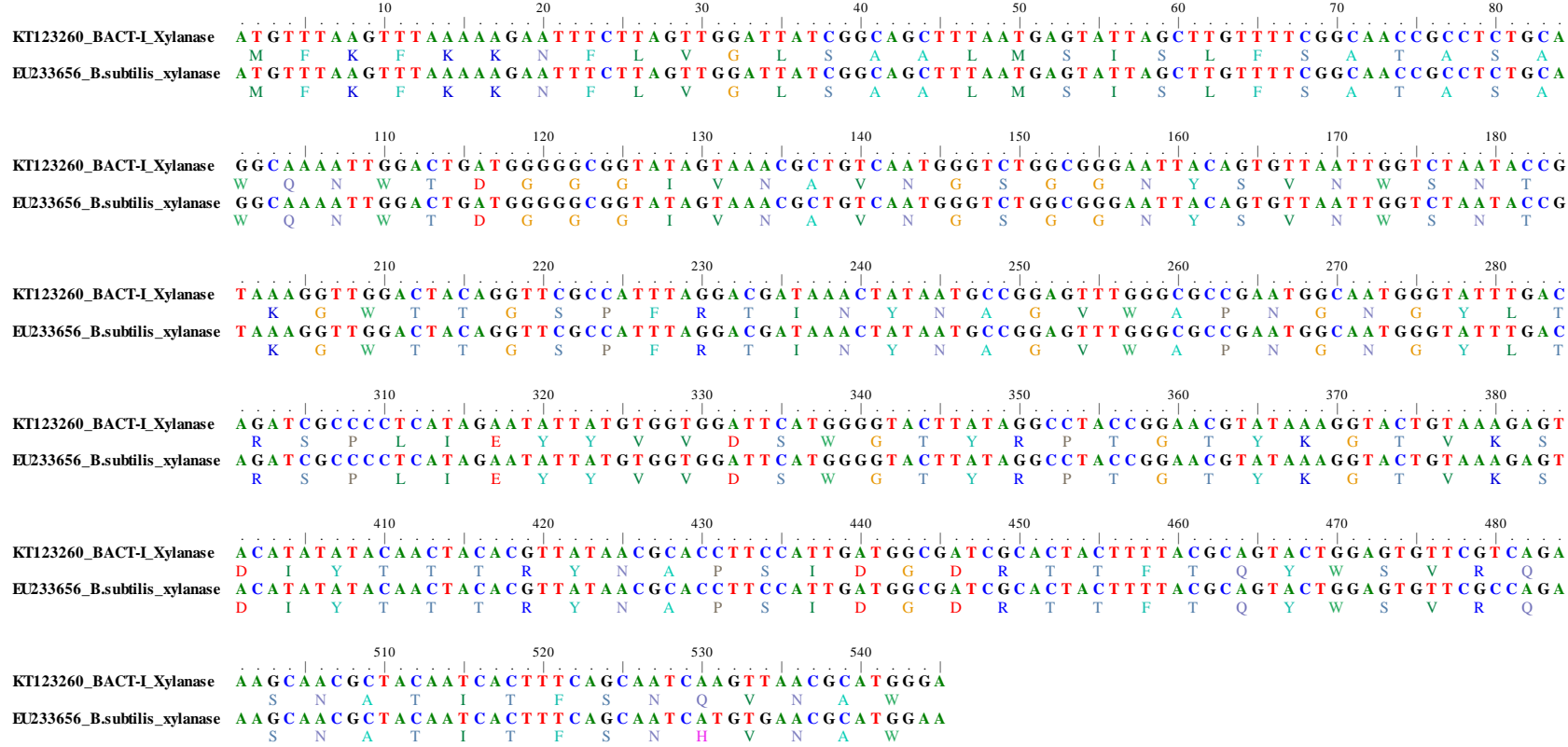

Figure 4: Nucleotide and deduced amino acid sequences of the xylanase gene (accession number: KT123260) from Bacillus subtilis (Bact-I) against with the nucleotide sequence of $\beta-1,4$ endo-xylanase gene retrieved form GenBank (EU233656).

For the preliminary experiment in this study, bacterial samples were isolated from the gut of $T$. ni (Hübner) larvae. Only different bacterial colonies were selected to screen for xylanase production in a xylan medium. Although we selected different colonies, only one isolate was found to be positive for xylanase production in our observations. For reasons of application, anaerobic bacteria are more difficult to cultivate and manipulate than aerobic bacteria. Thus, we focused only on aerobic bacteria which are able to grow at $37^{\circ} \mathrm{C}$. This temperature may not be suitable for anaerobic bacteria or certain species of insects, which usually grow at between 27-28 ${ }^{\circ} \mathrm{C}$ (Zhao et al., 2012). This is based on a recent study that showed the majority of microflora in insect intestines are anaerobic bacteria (Yun et al., 2014).

\section{ACKNOWLEDGEMENT}

The authors would like to thank the Graduate School of Thaksin University for financial support through Graduate Student Scholarship. We are also grateful to the Research and Development Institute of Thaksin University for supporting this project through its Research-based Strategies Fund for the year 2014. Special thanks to the Microbial Resource Management Research Unit of Thaksin University and the Department of Biology, Faculty of Science, Thaksin University for providing of the facilities. 


\section{REFERENCES}

Anand, A., Kumar, V. and Satyanarayana, T. (2013). Characteristics of thermostable endoxylanase and beta-xylosidase of the extremely thermophilic bacterium Geobacillus thermodenitrificans TSAA1 and its applicability in generating xylooligosaccharides and xylose from agro-residues. Extremophiles 17, 357-366.

Anand, A. A. P., Vennison, S. J., Sankar, S. G., Prabhu, D. I. G., Vasan, P. T., Raghuraman, T. and Vendan, S. E. (2010). Isolation and characterization of bacteria from the gut of Bombyx mori that degrade cellulose, xylan, pectin and starch and their impact on digestion. Journal of Insect Science 10, 1-20.

Bastawde, K. B. (1992). Xylan structure, microbial xylanases, and their mode of action. World Journal of Microbiology and Biotechnology 8, 353-368.

Beg, Q. K., Kapoor, M., Mahajan, L. and Hoondal, G. S. (2001). Microbial xylanases and their industrial applications: A review. Applied Microbiology and Biotechnology 56, 326-338.

Bhalla, A., Bischoff, K. M., Uppugundla, N., Balan, V. and Sani, R. K. (2014). Novel thermostable endoxylanase cloned and expressed from bacterium Geobacillus sp. WSUCF1. Bioresource Technology 165, 314-318.

Cordeiro, C. A. M., Martins, M. L. L., Luciano, A. B. and da Silva, R. F. (2002). Production and properties of xylanase from thermophilic Bacillus sp. Brazilian Archives of Biology and Technology 45, 413-418.

Faik, A. (2010). Xylan biosynthesis: News from the grass. Plant Physiology 153, 396-402.

Ghori, M. I., Ahmed, S., Malana, M. A. and Jamil, A. (2011). Corn stover-enhanced cellulase production by Aspergillus niger NRRL 567. African Journal of Biotechnology 10, 5878-5886.

Gusmão, D. S., Santos, A. V., Marini, D. C., deSouza, R. E., Peixoto, A. M. D., Júnior, M. B., BerbertMolina, M. A. and Lemos, F. J. A. (2007). First isolation of microorganisms from the gut diverticulum of Aedes aegypti (Diptera: Culicidae): New perspectives for an insectbacteria association. Memorias do Instituto Oswaldo Cruz 102(8), 919-924.

Himedia Biochemical identification kit. (2015). Hibacillus $^{\text {TM }}$ Identification Kit: Technical data manual. Available from

http://www.himedialabs.com/intl/en/products/Microbiol ogy/Ready-prepared-Media-Biochemical-IdentificationKit/100000195. [Access date September, 2015].

Huang, J. L., Wang, G. X. and Xiao, L. (2006). Cloning, sequencing and expression of the xylanase gene from a Bacillus subtilis strain B10 in Escherichia coli. Bioresource Technology 97, 802-808.

Kayserilioglu, B. S., Bakir, U., Yilmaz, L. and Akkas, N. (2003). Use of xylan, an agricultural by-product, in wheat gluten based biodegradable films: Mechanical, solubility and water vapor transfer rate properties. Bioresource Technology 87, 239-246.
Klindworth, A., Pruesse, E., Schweer, T., Peplies, J., Quast, C., Horn, M. and Glockner, F. O. (2013). Evaluation of general 16S ribosomal RNA gene PCR primers for classical and next-generation sequencingbased diversity studies. Nucleic Acids Research 41(1), e1.

Leartslarus, C., Ratanakhanokchai, K. and Kyu, J. L. (2002). Optimization of extraellular cellulase-free xylanase production by alkaliphilic Bacillus furmus K-1. KMUTT Research and Development Journal 1, 3-12.

Menon, G., Mody, K., Keshri, J. and Jha, B. (2010). Isolation, purification, and characterization of haloalkaline xylanase from a marine Bacillus pumilus strain, GESF-1. Biotechnology and Bioprocess Engineering 15, 998-1005.

Miller, G. L. (1959). Use of dinitrosalicylic acid reagent for determination of reducing sugar. Analytical Chemistry 31, 426-428.

Ninawe, S., Lal, R. and Kuhad, R. C. (2006). Isolation of three xylanase-producing strains of actinomycetes and their identification using molecular methods. Current Microbiology 53, 178-182.

Polizeli, M. L. T. M., Rizzatti, A. C. S., Monti, R., Terenzi, H. F., Jorge, J. A. and Amorim, D. S. (2005). Xylanases from fungi: Properties and industrial applications. Applied Microbiology and Biotechnology 67, 577-591.

Sanghi, A., Neelam, G., Jitender, S., Kalika, K., Ramesh, C. K. and Vijay, K. G. (2008). Optimization of xylanase production using inexpensive agroresidues by alkalophilic Bacillus subtilis ASH in solidstate fermentation. World Journal of Microbiology and Biotechnology 24, 633-640.

Selig, M. J., Knoshaug, E. P., Adney, W. S., Himmel, M. E. and Decker, S. R. (2008). Synergistic enhancement of cellobiohydrolase performance on pretreated corn stover by addition of xylanase and esterase activities. Bioresource Technology 99, 49975005.

Sheng, P., Xu, J., Saccone, G., Li, K. B. and Zhang, H. Y. (2014). Discovery and characterization of endoxylanase and beta-xylosidase from a highly xylanolytic bacterium in the hindgut of Holotrichia parallela larvae. Journal of Molecular Catalysis B-Enzymatic 105, 3340.

Subramaniyan, S. (2012). Isolation, purification and characterisation of low molecular weight xylanase from Bacillus pumilus SSP-34. Applied Biochemistry and Biotechnology 166, 1831-1842.

Yun, J. H., Roh, S. W., Whon, T. W., Jung, M. J., Kim, M. S., Park, D. S. and Bae, J. W. (2014). Insect gut bacterial diversity determined by environmental habitat, diet, developmental stage, and phylogeny of host. Applied and Environmental Microbiology 80, 5254-5264.

Zhao, J., Shi, B., Jiang, Q. R. and Ke, C. H. (2012). Changes in gut-associated flora and bacterial digestive enzymes during the development stages of abalone (Haliotis diversicolor). Aquaculture 338, 147-153. 